\title{
US agriculture's relationship to soil carbon
}

Ronald F. Follett

ugh Hammond Bennett is noted as having expressed after 24 years of studying soils of the United States that in his opinion soil erosion is the biggest problem confronting the farmers of the nation (Bennett and Chapline 1928). As summarized by Helms (2009), the concerns of Bennett and others eventually led to the formation of the Soil Erosion Service, which was the precursor to the Soil Conservation Service and was created within the USDA in 1935 (Bennett 1933). Here I provide a historic perspective of the use of US agricultural lands and soil carbon (C), compare amounts of soil organic carbon (SOC) in cropland versus land that has never been cultivated (native), and consider the future role of SOC in US agricultural lands. Within this context, the protection of SOC has been and will continue to be a necessary component to the economic and environmental health of US agriculture.

Little doubt can exist that among the great negative impacts related to the soil erosion observed by Bennett, if measured, would have been the severe loss of SOC associated with the eroding soil. The stable pool of SOC in soils is normally associated with the colloidal soil fraction and microaggregates and is depleted by soil degradative processes (Bajracharya et al. 1998) such as soil erosion. There is a linear decline in SOC content with accumulative soil erosion, and the enrichment ratio is about 3 to 5 (Lal 1998).

Accelerated erosion in the United States began with European settlement more than four centuries ago. In exploiting the soil and natural resources they found, these early settlers acted rationally and used the means available to them to wrest a living from the wilderness, a land mostly covered by seemingly limitless for-

Ronald F. Follett is the 2009 Hugh Hammond Bennett Award winner from the Soil and Water Conservation Society. Dr. Follett is research leader of the Soil-Plant-Nutrient Research Unit, USDA Agricultural Research Service, Fort Collins, Colorado. ests. Following the end of the Civil War in 1865, westward population movement and population growth were increasingly dynamic. Movement of the US population was aided by the Homestead Act of 1862 and by completion of the transcontinental railroad in 1869. Native American lands that had been seized by the government and their availability for settlement drew European immigrants whose numbers, coupled with the movement of US citizen settlers, increasingly opened the Great Plains and the western United States to agriculture. Historical records show that from the 1870s until about 1940 grain produced per unit of land area in the United States was essentially static (Follett 2007). Thus, along with the westward movement and growing populations, increasing areas of land were broken from their native condition.

The Dust Bowl of the 1930s provided a hard lesson about the use of large-scale, improper soil management that, coupled with drought, had devastating effects upon the nation and its society. This awakening did much for the conservation movement in the United States. As historian Robert Worster (1979, quoted in PBS 2006) wrote, "The ultimate meaning of the dust storms of the 1930s was that America as a whole, not just the plains, was badly out of balance with its natural environment."The awful and worsening drought conditions, coupled with the horrible effects of the Great Depression, eventually meant that millions of US citizens could no longer make a living from farming. By 1940 over 2.5 million people had moved out of the Great Plains. Life was simply unsustainable for many.

Following the shock of the Dust Bowl and after 1940, better land and resource management began to result, and-though not directly recognized at the time-better soil C management helped restore productivity to the land and the quality of the water and to conserve and help restore what were no doubt previous major losses of SOC.The lessons of the 1930s and 1940s resulted in greater awareness of the need for soil conservation practices and land set-aside programs, which would conserve land and soil productivity, and increase soil C. Land under the Soil Bank Act of 1956 was set aside primarily to divert cropland from the production of major crops and thus to decrease agricultural inventories but with a second purpose of establishing protective vegetative cover on land that needed conservation practices and protection from wind and water erosion.

Major subsequent technological innovations, described by Power and Follett (1987), occurred. Three highly important technological innovations appeared by the end of World War II:

1. Greater mechanization occurred, wherein most farms were using gasoline tractors that were increasing in size. There was increased use and availability of specialized agricultural machinery, including combines, planting equipment, high-clearance tillage equipment, and center-pivot irrigation rigs.

2. Crop varieties were improving with genetic advances in existing crops and the introduction of new crops (e.g., soybean) to push farmers toward monocultures, limited rotations, and increased crop-specific knowledge by farmers so that optimized yields could be obtained.

3. Agricultural chemical use, as typified by manufactured nitrogen $(\mathrm{N})$ fertilizer, became prominent after World War II, as did the use of agricultural pesticides.

These three technological advances after 1940 led farmers to increasingly grow a single or only a few crops and the development of increased confidence by farmers that, with the use of the above technologies, their crops would flourish.

Coupled with the above is a fourth technology - that of improved soil management (reduced tillage, enhanced crop residue management, water and precipitation conservation, and plant nutrient management). Improved soil management also includes use of crop rotations 
and cover crops. The various management components of this fourth technology have now become instrumental to decreasing soil erosion and protecting and restoring SOC.

\section{CONSERVATION PROGRAMS}

The Soil Bank Program was enacted in 1956 and consisted of two parts: an acreage reserve and a conservation reserve. In 1957, 8.7 Mha (21.4 million ac) of land were in the acreage reserve (Rasmussen et al. 1976), but Congress ended the program in 1958 (USDA Soil Conservation Service 1985). Through 1957, 2.63 Mha (6.5 million ac) were enrolled as part of its conservation reserve program (USDA Agricultural Research Service 1958). During its 10-year life, the Soil Bank Program diverted 11.5 Mha (28.4 million ac) to conservation practices (Economic Research Service 1963) (figure 1).

The Soil Bank Program was followed by two-similar long-term contract programs: the Cropland Conservation Program, authorized in 1962, and the Cropland Adjustment Program, enacted in 1965. The Agricultural Act of 1970 as part of a three-year program required farmers to keep a certain percentage of their land under conservation practices, and they could grow whatever they wanted on the rest of their land. However, by 1973 the demand for American farm products and their export was high because of diminished world grain stocks and worldwide inflation. Export demand and subsidies, devaluation of the US dollar, and the rise in farm commodity prices liquidated the stocks built up under previous price support programs (Rasmussen et al. 1976). With encouragement of USDA policy makers, US producers planted crops on marginal cropland and broke out and planted range and pasture lands. The Agricultural and Consumer Protection Act of 1973 placed emphasis on production to respond to "ever-growing world-wide demand for food and fiber" (USDA Soil Conservation Service 1985). Amazingly, by 1973 all USDA-subsidized croplandretirement programs were suspended and the conservation lessons of the 1930s appeared to have been forgotten. These activities continued until the early 1980s,

\section{Figure 1}

Idle and other cropland use from 1940 (USDA National Agricultural Statistics Service 2004, 2008; USDA Agricultural Research Service 1958; Aines 1963; Rasmussen et al. 1976).

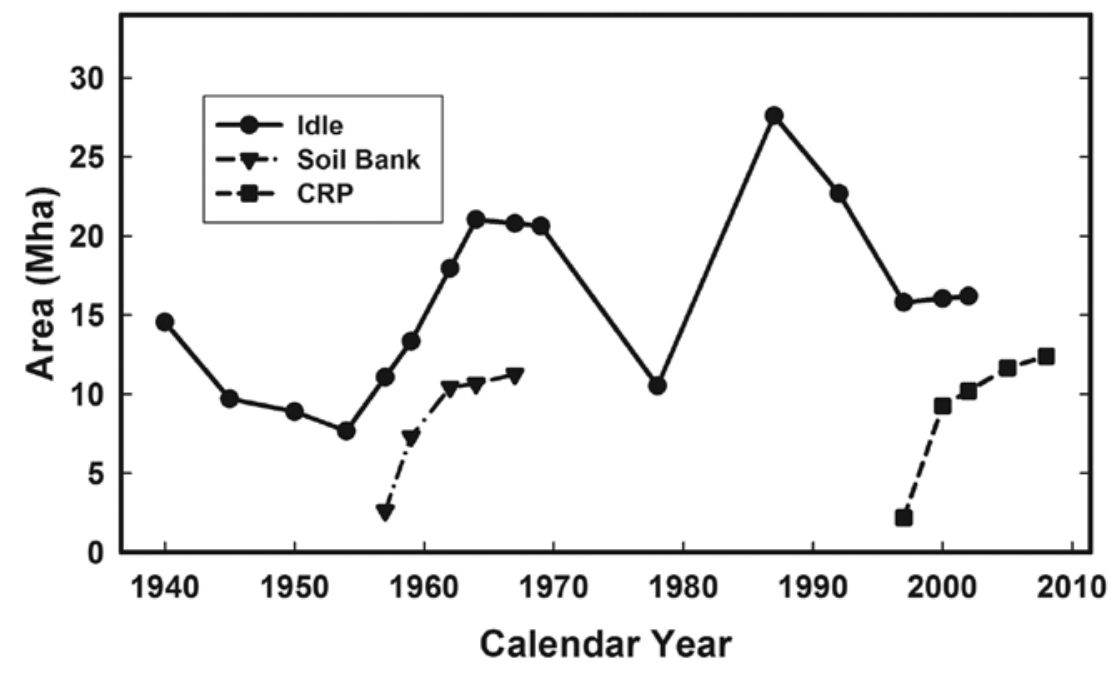

when overproduction and a stronger US dollar depressed prices and caused farm income to fall to its lowest level since the 1930s. Concurrent with the falling of farm income, acreage of idle lands also increased throughout the early 1980s (figure 1).

The National Resources Inventory in 1972 along with reports by the General Accounting Office indicated that unsustainable levels of annual soil losses were occurring (USDA Soil Conservation Service 1985). Implementation of the Soil and Water Conservation Act (RCA) of 1977 resulted in the collection of data showing that soil erosion and concurrent losses of soil organic matter (SOM) had increased to levels that were perhaps worse than those during the Dust Bowl years of the 1930s and that few enduring resource conservation benefits remained (Berg 1994). Soils once adequately treated or retired from cultivation had been tilled and planted to annual crops. The lesson from the 1970s was that there is a strong need for responsible soil-conservation policies at the national level and that the suspension of government programs supportive to conservation and reduced soil degradation had resulted in the rapid loss of the economic and societal benefits of soil $\mathrm{C}$ that had been accumulated under the Soil Bank Program.
Continued recognition of the adverse impacts of ongoing soil erosion resulted in key additional legislative authority being placed into the 1985 farm bill to implement a nationwide Conservation Reserve Program (CRP). Since then, idle cropland area has decreased and especially during the latter part of the 1990s acreages of land placed in the CRP have grown substantially (figure 1 ). As a result, the nearly 12.4 million ha (30.6 million ac) of land in CRP has exceeded the previous 11.5 Mha (28.4 million ac) that were in the Soil Bank Program (USDA National Agricultural Statistics Service 2008). Land placed in the CRP has been shown capable of sequestering millions of tons of SOC (Follett et al. 2001).The CRP explicitly identifies soil $\mathrm{C}$ sequestration as a factor for enrollment selection in the Environmental Benefits Index (EBI). However, SOC sequestration is a subcategory criterion factor under the "Air Quality Benefits from Reduced Wind Erosion" category of the EBI. Because enhanced soil C stocks have multiple benefits, SOC sequestration could be included in virtually all the EBI categories as a criterion or could constitute its own criterion for the EBI.

Highly important to the future is recognition that current CRP contracts will be expiring. Multiple benefits obtained from the CRP, including sequestered SOC, 
resulted from a very large investment of taxpayer funds over nearly 20 years. Accumulated benefits from CRP have not been adequately measured. Neither is it fully understood whether the lands under expiring CRP contracts will be adequately treated if they again are tilled and planted to annual crops. Lessons from the 1970s need not be repeated since newer technologies are feasible (Follett et al. 2009b). Responsible soil-conserving government programs and policies at the national level need to continue to support conservation and to protect economic and societal benefits, including those accumulated under the CRP.

Other USDA programs that encourage SOC sequestration (Follett and Reed forthcoming) include the Environmental Quality Incentives Program (EQIP) established in the 1985 farm bill, which provides financial assistance to producers to install and maintain conservation practices and soil, water, and natural resource enhancing practices on productive agricultural lands and systems, including grassland, rangeland, pasture land, and lands used for livestock production. Locally identified problems are specifically targeted by EQIP, and water quality objectives are given priority. In addition, the voluntary Conservation Innovation Grants (CIG) program awards EQIP funds and technical assistance to promote conservation and soil enhancement practices-including soil C sequestration-on private working lands, cropland, grassland, prairie land, improved pasture, and rangeland.

The recently enacted Food, Conservation and Energy Act of 2008i.e., the 2008 farm bill-not only contains new programs to help quantify environmental and societal benefits from land improvements and enable agricultural producers to increase soil $\mathrm{C}$, but also reinforces EQIP. The 2008 farm bill also authorizes an Environmental Service Markets (ESM) program within USDA, which explicitly recognizes agriculture's role in providing environmental benefits to society and can help prepare the sector to participate in emerging and existing markets, including carbon markets. The 2008 farm bill updates and extends the Conservation Security Program (CSP), established in the 2002 farm bill, and renames it the Conservation Stewardship Program. This program encourages comprehensive or systemwide stewardship of working agricultural lands.

Market-based incentives in support of agricultural conservation activities and terrestrial $\mathrm{C}$ sequestration on public and private lands can provide income-generation potential to accomplish a suite of environmental, natural resource, and ecosystem benefits enjoyed by society at large as well as the agricultural sector. These activities can potentially enhance SOC sequestration, and the degree to which they occur depends upon both future USDA programs and legislative initiatives. In the 111th US Congress, the leadership in both the House of Representatives and the Senate, with the support from the President, has indicated that passing mandatory legislation to curb US emissions of greenhouse gases to help combat climate change is of high priority. The House has now passed HR 2454 (Waxman-Markey) (US House of Representatives 2009). In the Senate, committees of jurisdiction have begun having hearings on potential legislation, with the Senate's leadership promising floor votes on a bill before year's end. It is widely believed the United States will enact or implement mandatory nationwide greenhouse gas emission reductions policies within 1 to 3 years.

\section{ATMOSPHERIC CARBON DIOXIDE}

The literature about climate change largely began in the early 1980s (Ausubel 1983; Lemon 1983; Waggoner 1983) and was accompanied by a broad awakening regarding the implications for US agriculture (Rosenberg 1982, 1988; Adams et al. 1990) and the potential role for soil C (Schlesinger 1986). Linkages between the soil C pool, global C cycle, and soils as a source or sink of atmospheric carbon dioxide $\left(\mathrm{CO}_{2}\right)$ stimulated early discussions regarding soil management as a possible strategy to reduce greenhouse gases (Dyson 1977; Jenny 1980). In 1990, then USDA Assistant Secretary Hess turned to the Council for Agricultural Science and Technology to ask on behalf of US farmers and foresters:
- What role does agriculture play in having adverse effects upon the climate?

- What should agriculture do to adapt to possible climate change?

- What can agriculture do from a positive standpoint to reduce emissions of greenhouse gases?

A subsequent report to USDA (also distributed to Congress, the United States Environmental Protection Agency, and other agencies) served as a resource for USDA attendees at the United Nations Framework Convention on Climate Change in Rio de Janeiro, Brazil in 1992 (Council for Agricultural Science and Technology 1992). The United States subsequently became a signatory country to the United Nations Framework Convention on Climate Change treaty. Much of the discussion in these early communications concerned the potential of agricultural systems to sequester C, and thereby to help remove some of the presently most abundant greenhouse gas, $\mathrm{CO}_{2}$, from Earth's atmosphere.

The problem of mitigating the increase of $\mathrm{CO}_{2}$ in the Earth's atmosphere remains one of the most pressing modern-day environmental issues (Intergovernmental Panel on Climate Change 2007). The change in atmospheric $\mathrm{CO}_{2}$ from pre-industrial levels of $280 \mathrm{ppm}$ to over $386 \mathrm{ppm}$ today is creating concern about managing future increases in $\mathrm{CO}_{2}$ and its effect on increasing atmospheric temperatures and changing weather patterns. $\mathrm{CO}_{2}$ is an important greenhouse gas that is exchanged in consequential amounts between terrestrial soil $\mathrm{C}$ pools and the atmosphere.

The exchange of $\mathrm{CO}_{2}$ from the atmosphere into stable $\mathrm{C}$ in the soil can sequester $\mathrm{CO}_{2}$, and the overall balance of this exchange constitutes the net $\mathrm{CO}_{2}$ flux of a crop production system. The effect of management on net $\mathrm{CO}_{2}$ emission needs to be weighed against the impact of these changes on system productivity to determine the most desirable management options. Field quantification regarding the effects of management on net $\mathrm{CO}_{2}$ emission (i.e., the net change of SOC stocks) is needed across a wide range of soils and agroecosystems so that biogeochemical models can be improved to permit accu- 
rate description of the impact of changes at field to regional scales.

\section{SOIL ORGANIC CARBON}

Within the United States, numerous ecosystems contribute to the exchange of atmosphere $\mathrm{CO}_{2}-\mathrm{C}$ and the SOC in the soil. Land area of the United States is about 930 Mha (2.3 billion ac), with about 263 Mha (650 million ac) as forestlands and another 237 Mha (586 million ac) of grasslands, pastures, and croplands (Lubowski et al. 2006). In this context, the USDA National Agricultural Statistics Service (2008) reports about 138 Mha (340 million ac) of cropland are used for crops. The area enrolled in CRP reached 12.4 Mha (30.6 million ac) in 2008 (figure 1) (USDA National Agricultural Statistics Service 2008). In one of a few regional experimental studies (across a 13-state region), Follett et al. (2001) reported that cropped lands planted to grass cover under the CRP sequestered SOC at a rate of $5.1 \mathrm{Mg} \mathrm{C} \mathrm{y}^{-1}\left(5.62 \mathrm{tn} \mathrm{yr}^{-1}\right)$ in the 0 to 20 $\mathrm{cm}$ (0 to $7.9 \mathrm{in}$ ) depth across the 5.6 Mha (13.8 million ac) represented in the study. Though impressive, the reported sequestration of SOC across the 13 states likely only represented replacement of part of the native SOC lost during a long period of cropping.

Follett et al. (2009a) extended the original sampling and reported on 67 sets of data representing 9 Mha (22.2 million ac) of native, cropped, and revegetated treatments throughout the United States (figure 2). The extensive survey provided much interesting information, but to use the data to estimate the equivalent amount of $\mathrm{CO}_{2}$ represented by the observed differences, the data needed to be area-weighted and statistically analyzed.

Figure 3(a) shows the area-weighted means of SOC as $\mathrm{kg}$ SOC ha per $10 \mathrm{~cm}$ for the 9 Mha (22.2 million ac) represented by 21 soil series at the sampling sites shown in figure 2 . On an areaweighted basis, 131,890 and $98,470 \mathrm{~kg}$ SOC ha ${ }^{-1}(117,670$ and $87,850 \mathrm{lb}$ SOC $\mathrm{ac}^{-1}$ ) were found in the top $100 \mathrm{~cm}(39.4$ in) of the native and cropped sites, respectively. Figure 3(b) shows the difference by depth increment between the areaweighed means for the two land uses. The

\section{Figure 2}

Coterminous US map showing location of soil organic carbon sampling sites (Soil Survey Division, USDA Natural Resources Conservation Service).

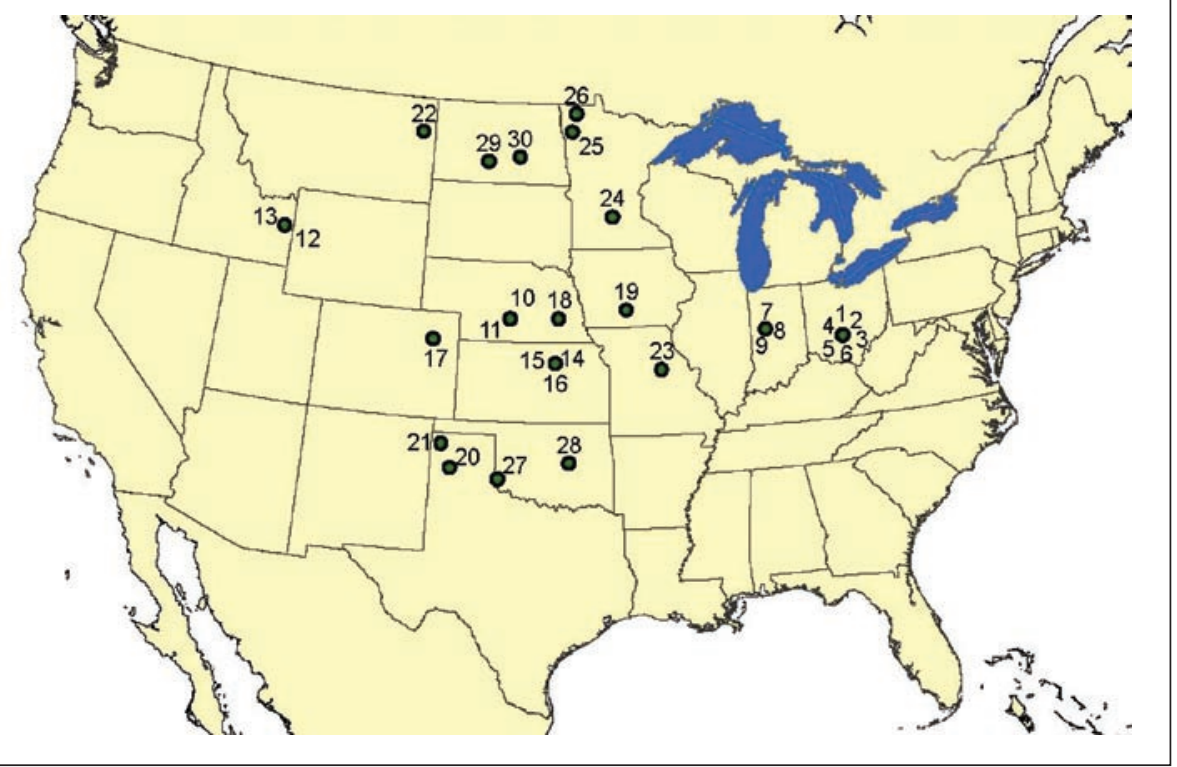

vertical axes on the graphs show the mean of each depth increment that was sampled. Thus, the 0 to $10 \mathrm{~cm}$ (0 to 3.9 in) depth increment is represented by a point at -5 $\mathrm{cm}(-2.0 \mathrm{in})$, the 10 to $20 \mathrm{~cm}$ (3.9 to 7.9 in) depth increment by a point at $-15 \mathrm{~cm}$ (-5.9 in), and on down to the 60 to 100 $\mathrm{cm}$ (23.6 to 39.4 in) depth being represented at a point at $-80 \mathrm{~cm}(-31.5 \mathrm{in})$, but as with the 30 to $60 \mathrm{~cm}$ (11.8 to $23.6 \mathrm{in}$ ) depth, representing mass of SOC per 10 $\mathrm{cm}$ (3.9 in) depth units within the 60 to $100 \mathrm{~cm}$ (23.6 to $39.4 \mathrm{in})$ depth increment and likewise for the 60 to $100 \mathrm{~cm}(23.6$ to 39.4 in) depth increment. The difference in SOC between the native sites and cropped sites (figure $3[\mathrm{~b}]$ ) was significantly different from zero at the 0 to $10 \mathrm{~cm}(0$ to $3.9 \mathrm{in})$ and 20 to $30 \mathrm{~cm}$ (7.9 to 11.8 in) $(\operatorname{Pr}>t=0.001)$, the 10 to $20 \mathrm{~cm}(3.9$ to 11.8 in $)(\operatorname{Pr}>t=0.01)$, and the 30 to $60 \mathrm{~cm}$ (11.8 to 23.6 in) $(\operatorname{Pr}>\mathrm{t}=0.05)$ depths, respectively. The difference in SOC between native minus cropped land for the 60 to $100 \mathrm{~cm}$ (23.6 to $39.4 \mathrm{in}$ ) depth was not significant.

The area-weighted data in figure 3 are for the $\sim 9$ Mha (22.2 million ac) represented and show that $28 \%$ and $23 \%$ of the SOC from the entire $100 \mathrm{~cm}$ (39.4 in) profile are within the 0 to $10 \mathrm{~cm}$ (0 to 3.9 in) depth increment of the native and cropped land use, respectively (figure 3[a]). Corresponding values for the 0 to 20 (0 to $7.9 \mathrm{in}$ ) and 0 to $30 \mathrm{~cm}$ (0 to $11.8 \mathrm{in}$ ) depths were $44 \%$ and $39 \%$ for the native and cropped land uses and 59\% and 53\% for the cropped land uses, respectively. However, when the metric of the "native minus cropped" is used to evaluate the area weighted loss of SOC from the 0 to 100 $\mathrm{cm}$ (0 to $39.4 \mathrm{in}$ ) depth, 43\%, 58\%, and $75 \%$ of the total loss is from the 0 to $10 \mathrm{~cm}$ (0 to $3.9 \mathrm{in}$ ), 0 to $20 \mathrm{~cm}$ (0 to $7.9 \mathrm{in}$ ), and 0 to $30 \mathrm{~cm}$ (0 to $11.8 \mathrm{in}$ ) depths, respectively, with the remaining $25 \%$ being from within the 30 and $100 \mathrm{~cm}$ (11.8 to 39.4 in) depth. These cumulative values support reports of soils research data on changes in SOC that occur within the top $30 \mathrm{~cm}$ (11.8 in). These data also emphasize the importance of improved soil management that controls soil erosion and protects the valuable topsoil and its associated SOC, nutrients, and other associated soil quality factors.

The observed area-weighted average decrease of SOC within the 0 to $10 \mathrm{~cm}(0$ to 3.9 inch) depth (native minus cropped) observed was $14,320 \mathrm{~kg} \mathrm{ha}^{-1}(12,780 \mathrm{lb}$ $\mathrm{ac}^{-1}$ ), a loss that when multiplied by the 9 Mha (22.2 million ac) of land area represented is equivalent to a difference of 1.3 $\mathrm{Tg}$ (1.43 million tn) SOC. The weighted 


\section{Figure 3}

Area weighted means with depth for 30 paired sites for (a) cropped and native sites and (b) mass of soil organic carbon of native minus cropped sites.

$\star * \star, * *, *$, and $n$.s. indicate the difference is significance at the $0.001,0.01,0.05$ confidence level, or not significant, respectively.

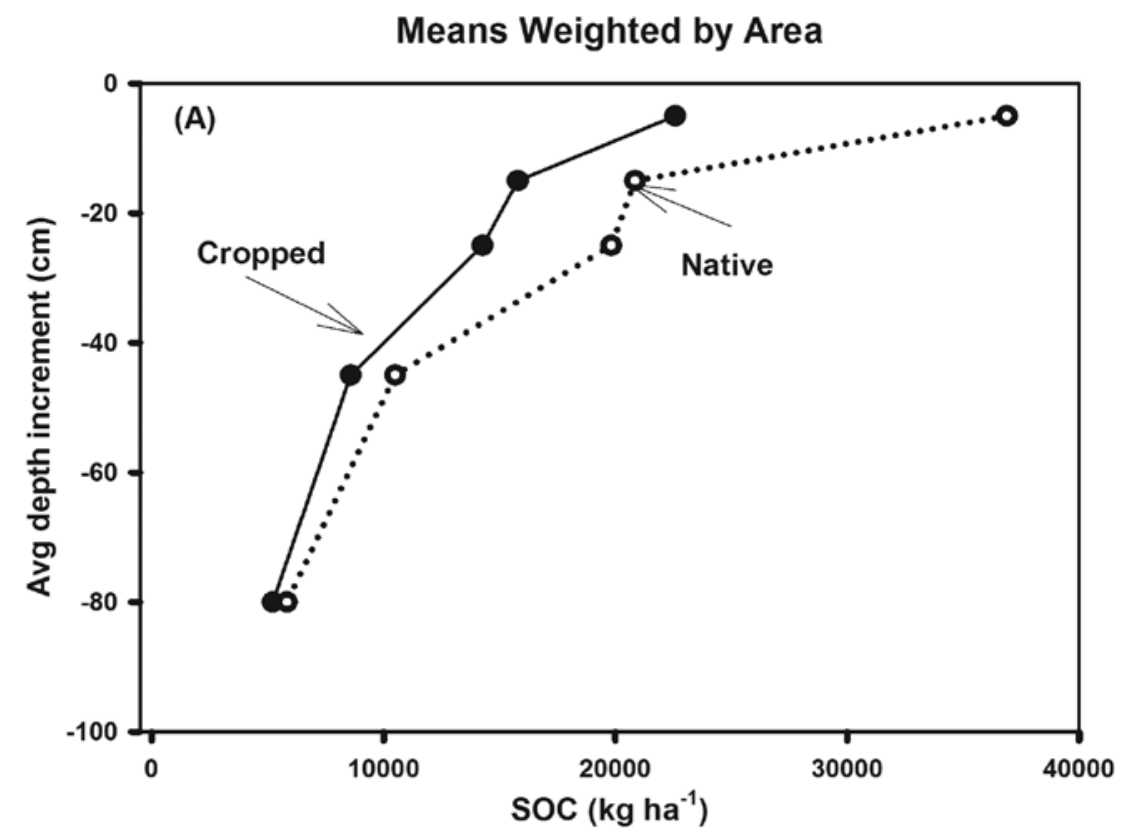

Mean Weighted Difference by Area

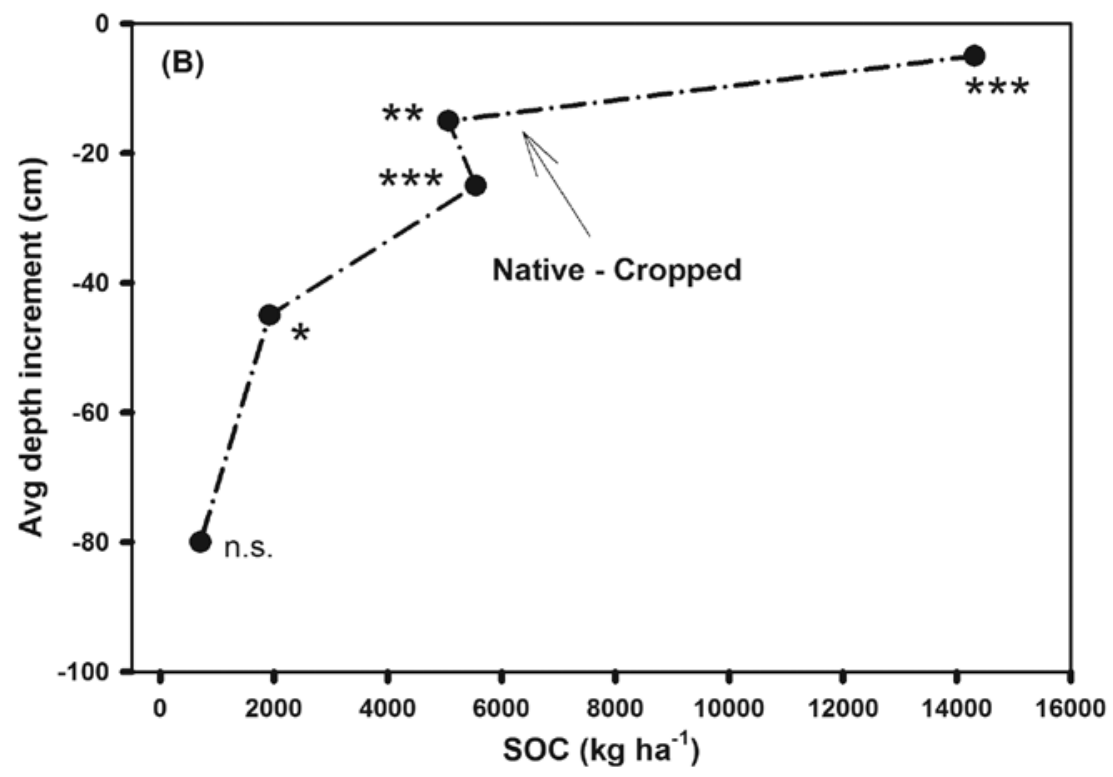

average decrease within the 0 to $100 \mathrm{~cm}$ (0 to 39.4 in) depth was $33,430 \mathrm{~kg}$ SOC $\mathrm{ha}^{-1}\left(29,825 \mathrm{lb} \mathrm{SOC} \mathrm{ac}^{-1}\right)$, or equivalent to $3.0 \mathrm{Tg}$ (3.31 million tn) SOC across 9 Mha (22.2 million ac) (table 1). The 9 Mha (22.2 million ac) represented by the soil series sampled in this study is $\sim 6.5 \%$ of the 137.6 Mha (340 million ac) of cropland used for crops in the United States (USDA National Agricultural Statistics Service 2008).

If similar differences exist between native versus cropped land across the entire 137.6 Mha (340 million ac) of US cropland, total SOC loss would be equivalent to as much as $46 \mathrm{Tg}(0.05 \mathrm{Pg} ; 50.7$ million tn) SOC, or potentially equivalent to 170 Tg (0.17 Pg; 187.4 million tn) $\mathrm{CO}_{2}$. There is no apparent way to determine rate at which net amounts of SOC were lost (or gained) since measured differences were accumulated over many decades. Neither is it possible to know how much of the net decrease in SOC resulted from its release into the atmosphere as $\mathrm{CO}_{2}$. Because of the dynamic exchange of $\mathrm{C}$ between the soil, the atmosphere, and potentially across the landscape, both losses and gains within specific sites occur over time as a result of the emission of $\mathrm{CO}_{2}$, sequestration of atmospheric $\mathrm{CO}_{2}$ where it becomes part of the SOM pool, potential additional losses or gains from soil erosion or deposition processes, and possible leaching of dissolved organic carbon. Regardless, and to provide a perspective, the difference reported here between native and cropped soil data amount to $170.5 \mathrm{Tg}$ (187 million $\mathrm{tn}$ ) difference in $\mathrm{CO}_{2}$ equivalents, an amount that is important because such an amount can help provide a reservoir within which SOC can be re-sequestered and contribute to the $32.2 \mathrm{Tg}$ (35.5 million tn) $\mathrm{CO}_{2} \mathrm{y}^{-1}$ offset reported in recent greenhouse gas inventories for US cropland soils (USDA 2008).

\section{A FUTURE ROLE FOR SOIL ORGANIC CARBON}

The loss of SOC during the 1930s, though much less recognized than loss of the topsoil, was a critical contributor to the devastation of the livelihoods for millions of families during that period of time. The importance of SOM has been recognized by farmers and land managers of soil productivity ever since the beginning of settled agriculture some eight thousand years or more ago. Soil is composed of many components including residual mineral matter from rock weathering, living organisms, the soil organic matter or humus that results from the decay of dead plants, water, and air. The interaction of a soil's components all contribute to its productivity, with perhaps SOC serving as a measure of how well a soil can serve the various present needs required of it by humans.

The contemporary needs for measuring SOC is still focused on agronomic 


\section{Table 1}

Area-weighted Tg soil organic carbon in 9 Mha of land under native vegetation, cropped, and difference (native - cropped) and the standard errors for each.

\begin{tabular}{lllllll}
\hline & \multicolumn{7}{l}{ Tg soil organic carbon } \\
\cline { 2 - 7 } Depth (cm) & Native & SE native & Cropped & SE cropped & Native - cropped & SE native - cropped \\
\hline 0 to 10 & 3.32 & 0.24 & 2.03 & 0.24 & 1.29 & 0.28 \\
10 to 20 & 1.87 & 0.17 & 1.42 & 0.17 & 0.45 & 0.16 \\
20 to 30 & 1.78 & 0.17 & 1.28 & 0.17 & 0.50 & 0.14 \\
30 to 60 & 2.83 & 0.22 & 2.31 & 0.22 & 0.52 & 0.24 \\
60 to 100 & 2.10 & 0.19 & 1.88 & 0.19 & 0.22 & 0.18 \\
0 to 100 & 11.90 & 0.20 & 8.90 & 0.20 & 3.00 & 0.40 \\
\hline Note: SE = standard error. & & & & & \\
\hline
\end{tabular}

or biomass production and soil fertility. Managing the SOC pool for immediate needs is based on enhancing agronomic production through alteration of the rate of SOM mineralization to release essential plant nutrients. Focusing primarily on seasonal crop production may accentuate higher microbial activity and associated emissions of $\mathrm{CO}_{2}$ and other greenhouse gases with a positive feedback on climate change. Thus, the environmental impact may be negative in terms of climate change, soil degradation, and water pollution. Depletion of the SOC pool may adversely affect soil quality by decreasing soil aggregate stability and lowering soil water retention and transmission.

There is increasing recognition of numerous ecosystem services that soils and SOC provide. Included is climate change mitigation through offsetting of carbon emissions resulting from fossil fuel combustion and other anthropogenic activities. While agronomic or biomass production and food security remain important, environmental issues and ecosystem services are recognized to a greater degree now

\section{Table 2}

Soil carbon sequestration for immediate needs versus future demands (Lal and Follett 2009).

\begin{tabular}{lll}
\hline Parameter & Immediate needs & Future demands \\
\hline Production & Immediate gains & Sustainability \\
Processes & Mineralization & Humification \\
Transformation & Release of nutrients & Immobilization of nutrients \\
Microbial activity & High & Low \\
Feedback & Positive & Negative \\
Soil quality & Degradative & Restorative \\
Environmental benefits & None and low & High and substantial \\
\hline
\end{tabular}

\section{REFERENCES}

Adams, R.M., C. Rosenzweig, R.M. Pearl, J.T. Ritchie, B.A. McCarl, J.D. Glyer, R.B. Curry, J.W. Jones, K.J. Boote, and L.H. Allen Jr. 1990. Global climate change and U.S. Agriculture. Nature 345:219-224.

Aines, R.O.1963. Release of Land from Conservation Reserve Contracts. Research Report No. 34. Washington, DC: USDA Economic Research Service.

Ausubel, J.H. 1983. Historical note. In Changing Climate, 153-185. Washington, DC: National Academy Press.

Bajracharya, R.M., R. Lal, and J.M. Kimble. 1998. Soil organic carbon distribution in aggregates and primary fractions as influenced by erosion phases and landscape position. In Soil Processes and the Carbon Cycle, ed. R. Lal, J.M. Kimble, R.F. Follett, and B.A. Stewart, 353-367. Boca Raton, FL: CRC Press.

Bennett, H.H. 1933. Letter to Harold Ickes, September 18, 1933. File 1-275 Soil Erosion, Central Classified Files, Record Group 48. College Park, MD: National Archives and Records Administration.

Bennett, H.H., and W.R. Chapline. 1928. Soil Erosion: A National Menace. USDA Circular 33. Washington, DC: US Government Printing Office.

Berg, N.A. 1994. The genesis of the CRP. In When Conservation Reserve Program Contracts Expire: The Policy Options, 7-12. Conference Proceedings, Arlington, Virginia, February 10-11, 1994. Ankeny, IA: Soil and Water Conservation Society.

Council for Agricultural Science and Technology. 1992. Preparing U.S. Agriculture for Global Climate Change. Report 119. Ames, IA: Council for Agricultural Science and Technology.

Dyson, FJ. 1977. Can we control the carbon dioxide in the atmosphere? Energy 2(74):96-103.

Follett, R.F. 2007. Economic and societal benefits of soil carbon management: Cropland and grazing land systems. In Soil Carbon Management: Economic, Environmental, and Societal Benefits, ed. J.M. Kimble, C.W. Rice, D.R. Reed, S. Mooney, R.F. Follett and R. Lal, 99-128. Boca Raton, FL: CRC Press.

Follett, R.F., J.M. Kimble, E.G. Pruessner, S. SamsonLiebig, and S. Waltman. 2009a. Soil organic C stocks with depth and land use at various U.S. sites. In Soil Carbon Sequestration and the Greenhouse Effect, 2nd ed., ed. R. Lal and R.F. Follett, 29-46. SSSA Special Publication 57. Madison,WI: Soil Science Society of America. 
Follett, R.F., and D.A. Reed. Forthcoming. Soil carbon sequestration in grazinglands: Societal benefits and policy implications. Rangeland Ecology and Management.

Follett, R.F., S.E. Samson-Liebig, J.M. Kimble, E.G. Pruessner, and S.W. Waltman. 2001. Carbon sequestration under the Conservation Reserve Program in the historic grassland soils of the United States of America. In Soil Carbon Sequestration and the Greenhouse Effect, ed. R. Lal, 27-40. SSSA Special Publication 57. Madison, WI: Soil Science Society of America.

Follett, R. F., G.A.Varvel, J.M. Kimble, and K.P.Vogel. 2009b. No-till corn after bromegrass: Effect on soil $\mathrm{C}$ and soil aggregates. Agronomy Journal 101(2):261-268.

Helms, D. 2009. Hugh Hammond Bennett and the creation of the Soil Erosion Service. Journal of Soil and Water Conservation 64(2):68A-74A.

Intergovernmental Panel on Climate Change. 2007. Climate Change 2007: Mitigation of Climate Change. Working Group III. Cambridge: Cambridge University Press.

Jenny, H. 1980. Alcohol or humans? Science 229:444.

Lal, R. 1998. Land use and soil management effects on soil organic matter dynamics on alfisols in western Nigeria. In Soil Processes and the Carbon Cycle, ed. R. Lal, J.M. Kimble, R.F. Follett, and B.A. Stewart, 109-126. Boca Raton, FL: CRC Press.

Lal, R., and R.F. Follett, eds. 2009. Soil Carbon Sequestration and the Greenhouse Effect, 2nd ed. SSSA Special Publication 57. Madison, WI: Soil Science Society of America.

Lemon, E.R., ed. 1983. CO2 and plants-the response of plants to rising levels of atmospheric carbon dioxide. In American Association for the Advancement of Science Symposium Series 84, Athens, Georgia, May 23-28, 1982. Boulder, CO: Westview Press.

Lubowski, R.N., et al. 2006. Major Uses of Land in the U.S., 2002. Economic Information Bulletin 14. Washington, DC: USDA Economic Research Service. http://www.ers.usda. gov/Publications/EIB14/.

PBS. 2006. The American Experience Surviving the Dust Bowl. www.pbs.org/wgbh/amex/dustbowl/peopleevents/pandeAMEX06.html.

Power, J.F., and R.F. Follett. 1987. Monoculture. Scientific American 255(3):78-86.

Rasmussen, W.D., G.L. Baker, and J.S. Ward. 1976. A short history of agricultural adjustment, 1933-1975. Agricultural Information Bulletin 391. Washington, DC: USDA Economic Research Service.
Rosenberg, N.J. 1982. The increasing CO2 concentration in the atmosphere and its implications on agricultural productivity: II. Effects through CO2-induced climatic change. Climate Change 4:239-254.

Rosenberg, N.J. 1988. Global climate change holds problems and uncertainties for agriculture. In U.S. Agriculture in a Global Setting: An Agenda for the Future, ed. M.A. Tutwiler, 203-218. Washington, DC: Resources for the Future.

Schlesinger, W.H. 1986. Changes in soil carbon storage and associated properties with disturbance and recovery. In A Changing Carbon Cycle: A Global Analysis, ed. J.R. Trabalka and D.E. Reichle, 194220. New York: Springer-Verlag.

USDA. 2008. U.S. Agriculture and Forestry Greenhouse Gas Inventory: 1990-2005.Technical Bulletin 1921. Washington, DC: Global Change Program Office, Office of the Chief Economist, USDA. http://www.usda.gov/oce/global_ change/AFGGInventory1990_2005.htm.

USDA Agricultural Research Service. 1958. The Conservation Reserve Program of the Soil Bank. Agricultural Research Bulletin 185. Washington, DC: USDA.
USDA National Agricultural Statistics Service. 2004. Washington, DC: US Government Printing Office.

USDA National Agricultural Statistics Service. 2008. Washington, DC: US Government Printing Office. http://www.nass.usda.gov/Publications/ Ag_Statistics/2008/TOC2008.pdf.

USDA Soil Conservation Service. 1985. Soil and Water Conservation, Background for 1985 Farm Legislation. Agricultural Information Bulletin 486. Washington, DC: USDA.

US House of Representatives. 2009. American Clean Energy and Security Act of 2009. Washington, DC: US House of Representatives. http://energycommerce.house.gov/Press_111/20090515/ hr2454.pdf.

Waggoner, P.E. 1983. Agriculture and a climate changed by more $\mathrm{CO} 2$. In Changing Climate, 383-418. Washington, DC: National Academy Press.

Worster, D.F. 1979. Dustbowl - the southern plains in the 1930s. New York: Oxford University Press. 